\title{
The Regulatory Framework governing Mobile Telecommunication Sector in Cameroon: A Blessing or a Curse in a Digital Economy?
}

Kinga Hellen Kimah"

Ph. D Research Candidate, Graduate Teaching Assistant (Moniteur), Faculty of Law and Political Science, University of Bamenda, Bamenda, Cameroon

DOI: $\underline{10.36348 / \text { sijlcj.2020.v03i01.003 }}$

| Received: 30.12 .2019 | Accepted: 07.01.2020 | Published: 22.01 .2020

*Corresponding author: Kinga Hellen Kimah

Abstract

It is worth noting that mobile telephony has revolutionised the way people and businesses carry out their daily life activities worldwide and Cameroon in particular. In this regard, telecommunications and information technology is of utmost important in our social life, the economy, the business and education among others. Regrettably, the interacting innovations in products, services and technologies with a general convergence or blurring of distinctions between platforms, products and services has greated enormous challenges in the mobile telephony sector. From the forgoing, there is the need for regulatory measures in the mobile telephony sector in Cameroon in order to enhance its digital economy. This paper therefore, seeks to examine the fundamental principles of mobile telecommunications sector in Cameroon. This paper also aims at identifying the regulatory mechanisms with deterrent sanctions and fundamental rights and obligation of regulatory bodies (telecom operators) and appraises the current status of mobile telephony in Cameroon. In order to attain the above objectives, we employed doctrinal and analytical research methodology. This paper therefore, conclude with a number of recommendations which if effectively implemented and enforced, will go a long way to improve on the regulatory frameworks governing mobile telecommunication sector in Cameroon as the country strive towards emergence by 2035.

Keywords: Regulation-Mobile-Telecommunication-Sector-Legal-Cameroon.

Copyright @ 2020: This is an open-access article distributed under the terms of the Creative Commons Attribution license which permits unrestricted use, distribution, and reproduction in any medium for non-commercial use (NonCommercial, or CC-BY-NC) provided the original author and source are credited.

\section{INTRODUCTION}

The world is a global village which has experienced lots of transformation since the early 1970 s, and one of these sporadic changes is the telecommunication sector [ 1 ]. Information Technologies (IT) revolutionised the way people and businesses carry out their daily life activities worldwide. This has resulted in a huge change of the individual's life in business and private settings. New and sophisticated breakthroughs in high technology encourage companies to introduce technological innovations rapidly into their business practices. The United States Space Programme has benefited immensely from rapid development in high-tech and today's information and communication technology. In many parts of the developed world, cellular, satellite,

\footnotetext{
${ }^{1}$ This can be experienced especially when the use of internet and mobile telephones has been in the increase, since many believe the coming of these aspects has increase and facilitates the transmission of information and acts as a tool of communication between people.
}

and wireless technologies combined with innovative business practices are beginning to make up for the shortcomings of the traditional wire line technology[2]. Thus, there is no doubt that one of today's realities is an extremely fast development of high-technology.

In today's world, not only are we surrounded by technology, but our primary means of reaching others in far and near places are mediated by technology. Accordingly, technology is progressively effacing the two previous environments: nature and society. It is asserted that modern man cannot live without gadgets. This is what makes human subservient to technology rather that technology being subservient to humanity [3 ].Therefore, if Cameroon must be part of

\footnotetext{
${ }^{3}$ Aduwa-Ogiegbaen, S. E., \& Iyamu, E. O. S. (2005). Using Information and Communication Technology in Secondary Schools in Nigeria: Problems and Prospects. Educational Technology \& Society, Vol.8 , No.1, pp.104-112.
} 
developed world in the near future, it must embrace technology and discard some of the old habits and perspectives and retool completely. There is need for the country to re-strategize and expand its vision so as to cope with the challenges of technological society [4].

Cameroon was not left out of this global telecommunication transformation. A vast and fast transition has been observed during the last two decades in Cameroon especially in the domain of mobile telecommunication that has completely given a decent burial to fixed telephone lines. The regulation of mobile telecommunication under common law has as kingpin reform that was meant to revamp and liberalised the sector through the participation of private sector to meet the changing needs of Cameroonians both in their social and business life, as well as ensuring effective integration into the global context. The country has enacted a series of laws and regulations [5], and even initiating a set of institutions whose main function is seeing that the available telecommunication operators respect the available standard in the functioning and management of their services.

There have been several national initiatives aimed at stimulating the use of ICTs, as a development tool to alleviate poverty and other challenging issues. These include: identification of ICTs as an enabler in achieving most of the activities identified in the Poverty Reduction Strategy Paper (PRSP) in 2003 and formulation of a sectorial strategy in the field of telecommunications and ICTs by the Ministry of Posts and Telecommunications in 2005[6]. Alongside these activities, several initiatives for the development and deployment of ICTs are underway within government departments in Cameroon. These include: the formulation of a government action plan for an information and knowledge-based society by the Ministry of Scientific Research and innovation, the implementation of an ICT development programmed by the Ministry of Higher Education, the creation of multimedia resource centers in secondary and high schools within the Ministry of Secondary Education, the implementation of the audiovisual sector liberalization option by the Ministry of Communication, the implementation of the National Governance Programmed by the Prime Minister's Office, the introduction of ICTs in the management of State personnel by the Ministry of Public Service and Administrative Reform, the computerization of the national identity card by the Delegation of National Security, and the computerization of the electoral

\footnotetext{
5 Ibid, p.105.

${ }^{4}$ Republic of Cameroon. (2009). CAMEROUN VISION 2035.

${ }^{5}$ See Law no. 98/014 of 14 July 1998 to govern telecommunication in Cameroon modified and completed by law no 2005/013 of29 December 2005.
}

${ }^{6}$ NAICT, Loc. cit. process by the defunct Ministry of Territorial Administration and Decentralization[7]. These national initiatives are supported by other external initiatives, such as: the initiative of the Economic Commission for Africa (ECA) on defining the National Information and Communication Plan (NICI Plan); the UNDP initiative on an ICT policy in Cameroon within the framework of the Second Tokyo International Conference for African Development (TICAD II); the International Telecommunications Union (ITU) support to the formulation of MINPOSTEL sector strategy; and support to the development of community and rural radios by UNESCO[8]. Thereby increasing the chances of improving the quality of lives of their citizens [9].

Up till the late 80 s, the telecommunication industry in Cameroon was the exclusive preserve of the State. The State assumed the sole responsibility of provider. There was little or no concern about regulating may be, because the state presumed it was doing 'just the right thing'. The state could supply limited services to a limited population with the available resources at the time under the auspices of the Ministry of Post and Telecommunication (MINPOSTEL), with their main products being postal services and fixed telephone services. But as the $80 \mathrm{~s}$ phased out, the $90 \mathrm{~s}$ ushered in strong globalisation trends. Ensnared by the goodies of globalisation and its tantalising offers, both the state and its citizens yearned to join in the trend.

In June 1990, the President of the Republic Issued a Presidential Order, ushering in public/private partnerships in the provision of public services such as telecommunication services. The telecommunication sector was added to the programme in June 1995. In July 1998, the Telecommunications Act was promulgated [10]. It established the Telecommunication Regulatory Agency and attributed sector responsibilities to a variety of players: the operation of telecommunication networks to operators, regulatory matters, i.e. application of the rules and supervision of operators, to a regulatory body, the definition of sector policy and the enactment of market regulations to the telecommunication administration. In September of the same year, two public enterprises, CAMTEL for the fixed telephone service and CAMTEL Mobile for the mobile telephone service, were set up to take over the telecommunication activities of the Ministry of Post and Telecommunications and of the public enterprise called INTELCAM, which was in charge of operating and developing international telecommunication installations. The Telecommunication Regulatory Agency was set up at the same time. Immediately after,

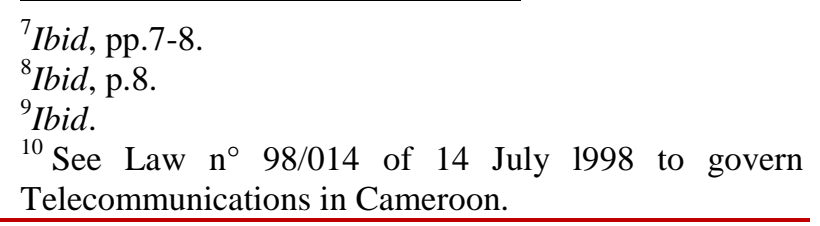


the sale of a mobile telephone license and the process of privatizing CAMTEL and CAMTEL Mobile got under way[11].

The expansion trend introduced by Law no. 98/014, ushered in new services and entrants into the industry. Cameroon Telecommunications Mobile (CAMTEL Mobile) was established. However, this service was later on privatised through concession agreement with Societe Camerounaise des Mobiles (SCM), which later on became Orange Cameroon. Shortly after, another concession convention was signed by CAMTEL with Mobile Telephone Network (MTN). Hence, MTN and Orange Cameroon multinational enterprises joined Camtel as the major operators within the telecommunication enterprise in Cameroon. While MTN and Orange Cameroon are multinational enterprises interested in maximising profits in the course of their business operations shared the market with Camtel, charged with a double function of both provider and over all regulator of the industry, through TRB. In fact, the privatization of CAMTEL Mobile was completed in February 2000. The privatization of CAMTEL is not yet complete. In less than two years, the sector underwent sweeping change. Suffice it to mention one indicator: in January 2000 there was one mobile telephone operator with about 5000 subscribers; on 31 March 2001 there were two operators with over 140000 subscribers. This rapid and in-depth transformation is taking place within a constantly improving legal framework [12].

The 1998 laws provide the legal backing for ICT evolution in Cameroon [13]. These laws brought an end to monopoly control in the telecommunication sector in Cameroon. They gave birth to telecoms liberalization and privatization, ushering in new players in telecommunications and encouraging investment in ICT. Further progress in legislation was made in 2001, instituting minimum service standards in the telecommunications sector through a series of decrees laying down the modalities for the operation of telecommunications networks and the provision of telecommunications services[14]. These developments led to an opening up of citizens' and business demand for ICT availability [ 15 ]. However, the rapid development of ICT globally also has led to the growth

\footnotetext{
${ }^{11}$ International Telecommunication Union, (May 2001). 'Telecommunication Sector Reform: Cameroon's Experience', Africa Regional Preparatory Meeting for the World Telecommunication Development Conference (WTDC-02), Yaoundé (Cameroon), P. 3.

${ }^{12}$ Ibid, p. 4.

${ }^{13}$ Asongwe, P. N. (2012). 'The Government and the Cameroon Cyber security Legislation 2010: Opportunities and Challenges', The African Journal of Information and Communication, Issue.12, p.157.

${ }^{14}$ See Law No.2001/0130 of 23 July 2001.

${ }^{15}$ Asongwe, P. N. Op. Cit., p. 157.
}

of new forms of problems with respect to customer's rights in Cameroon. This is because in spite of the investments made, the coverage rate and quality of service offered had remained largely inadequate [16] The process was carried out not only by defining the conditions and mechanisms liable to guarantee the sector's opening to private initiative, but also by enacting regulations and taking measures intended to enable the sector to play the decisive role incumbent on it in Cameroon's economic development [17].

\section{Why regulate the telecommunication sector in cameroon?}

To understand the role of regulation in ensuring the growth and development of the information and communications technology (ICT) sector and the mobile telephone sub-sector in Cameroon, the requirement of a strong legal and regulatory framework for effective regulation is fundamental. To better achieve this objective, it is necessary to discuss the reasons for regulation. This need acts as an opener, given the structural changes in the telecommunications sector from monopoly to competition, and the importance of regulation in transitioning to an effective competitive environment and fostering the long-term development of the ICT market. The need for regulation varies depending on the conditions of the marketplace. While the design of the regulatory framework may differ, certain critical elements should be included in an effective regulatory framework, such as the functional aspects of the regulatory authority; decision-making processes; accountability; consumer protection, dispute resolution and enforcement powers [18]. Consideration and proper implementation of these features are key elements for creating an enabling environment for development of the sector and for increased consumer welfare. From the abovementioned, the obvious question is what is regulation? Regulation may be defined as 'Any rule endorsed by government where there is an expectation of compliance' [19].

Prior to the telecommunications sector reforms undertaken in Cameroon, telecommunications services were largely provided under monopoly conditions, by

\footnotetext{
${ }^{16}$ International Telecommunication Union. (2001). Op. Cit., P. 3.

${ }_{18}^{17}$ Ibid.

18 Blackman, C. \& Srivastava L. (Eds). (2010). Telecommunications Regulation Handbook, Tenth Anniversary Edition, The International Bank for Reconstruction and Development / The World Bank, InfoDev, and The International Telecommunication Union, p.9.

19 Australian Government (2014). The Australian Government Guide to Regulation, Commonwealth of Australia, Department of the Prime Minister and Cabinet, p.3. Available at www.cuttingredtape.gov.au, (Accessed on June 22, 2018).
} 
state entities. The administration in charge of telecommunications activities in Cameroon is the Ministry of Posts and Telecommunications (MINPOSTEL) established at independence. But seeing that communications is the knot which ties both the national and international business community together and that such an activity must only be run by a structure with a business outlook, the government of Cameroon, created the international telecommunications corporation of Cameroon, commonly known and called by its French acronym INTELCAM, by law n ${ }^{\circ} 82-539$ of 28 October 1982. While this state corporation managed international telecommunications activities, the agency for the commercialisation of telecommunications (ACTEL) was created alongside to take care of the internal telecommunications network [20]. This is clear evidence that from the onset, the operator and regulator for telecommunications services was the government; therefore, no regulatory independence existed. This classic model of supply generally concentrated policy-making, regulatory, frequency management and network operating responsibilities in a single entity. ${ }^{21}$ This first phase was characterised by a firm state grip over the sector.

In the 1990s, partly as a result of national, regional and multilateral efforts, Cameroon introduced the first wave of reform by privatising her national operator [22]. It took effect from the reform of the telecommunications laws, with the enactment of Law $\mathrm{N}^{\circ} .98 / 014$ of 14 July 1998 to Govern Telecommunications in Cameroon. In the second wave of liberalisation, which sometimes occurred simultaneous with the privatisation or followed soon thereafter, Cameroon began allowing the introduction of new services (e.g., mobile services and value-added services) into the market. In fact, article 2(1) of the 1998 Telecommunication Law was to the effect that:

'This law shall apply all over the territory of Cameroon to the various telecommunications services, provided by any telecommunications enterprise regardless of its legal status, the location of its head office or main establishment and the nationality of the owners of its capital or that of its managers'.

This provision introduced competition into the market, with the national operator diversifying her services. In accordance to the terms of this law "CAMTEL Fixe" was created to manage the fixed telecommunications network whether national or

${ }^{20}$ See generally Baaboh F., H. 'Telecommunications Law in Cameroon'.

${ }^{21}$ International Telecommunication Union (ITU), ICT Regulation Toolkit, Module 6. Legal and Institutional Framework, p.8.

${ }^{22}$ Cameroon followed this wind of change, with the privatisation of its national Operator, Camtel. international, while "CAMTEL Mobile" managed the mobile/cellular network. These new services generally opened direct competition with the national operator, which had been granted an exclusivity over the fixedline and optical fibre operations. This is a resounding warning that full competition has not been introduced in Cameroon.

Fundamental principles, rights and obligations on the regulation of mobile telecommunications in cameroon

Although the aim of a regulator is to ensure that the sector is working properly and that consumer and other stakeholder interests are protected in a fair and balanced manner, an effective regulatory framework is the vehicle of credible market entry, as well as compliance with and enforcement of existing regulations[23]. To achieve these, the government need to create and maintain an environment conducive to good governance and regulatory success, by integrating rights, responsibilities and corresponding duties on operators, to better achieve its objectives. Since regulation is not only an affair of the regulators, the telecommunication operators have an important role to play; only when they duly perform these obligations, in strict compliance with those fundamental principles of telecommunication regulation, can it be said that the regulatory processes have been fully accomplished. The regulatory process in Cameroon is not left out, as the existing legal framework has clearly set out some general principles which are incumbent on telecommunications operators.

\section{General Principles governing Mobile Telecommunication Sector in Cameroon}

These general principles are a set of moral rules inherent on telecommunications operators, to contribute in the regulatory process. The idea behind it is to engage operators during their access regimes for the provision of telecommunications services, to adhere to these principles, to ensure an effective, efficient and transparent management of the regulation in force [24]. Principles in this context are generally considered as the moral rules and believe that influence the actions of telecommunications operators. These principles are discernible to wit

23 Blackman, C. \& Srivastava L. (Eds). (2010). Telecommunications Regulation Handbook, Tenth Anniversary Edition, The International Bank for Reconstruction and Development / The World Bank, InfoDev, and The International Telecommunication Union, p.14.

${ }^{24}$ See generally article 4 of Décret No.2012/1638/PM du 14 Juin 2012, fixant les modalités d'établissement et/ou d'exploitation des réseaux et de fourniture des services des communications électroniques soumis au régime de l'autorisation. 


\section{Principle of Technology Neutrality}

Under the framework for quality of service in the scope of net neutrality and regarding end-user rights, end-users should be able to decide what content they want to send and receive, and which services, applications, hardware and software they want to use for such purposes, without prejudice to the need to preserve the integrity and security of networks and services. In order to prevent degradation of service and the hindering or slowing down of traffic over networks, countries ensure that the regulatory authority is able to set minimum QoS requirements on an undertaking or undertakings providing public communications networks. The regulatory authority has the discretion to decide whether to apply any necessary minimum QoS requirements to one, to several, or to all ISPs, and will be able to impose minimum QoS requirements after having identified an instance or a risk of degradation of service, or hindering or slowing down of traffic.

In Cameroon, this fundamental principle is not properly stated under the 1998 Law on Telecommunications. It barely suggests that, subject to the licensing and/or authorisations regimes, the specification of neutrality of services is required [25]. Implicit in these specification, are the requirements relating to the conditions of permanency, availability and quality of service, subject to the principle of neutrality. A further specification of confidentiality is anticipated with respect to messages transmitted. This principle emanates from the respect of the technical prescriptions concerning access to the service, its interconnection with other support services and operating compatibility therewith' [26].

With respect to mobile internet, or internet services in general, the main regulatory goals of net neutral Internet access services QoS are targeted at: achieving the overarching objective of guaranteeing access to content for the interest of citizens; ensuring that electronic communications networks run smoothly, in other words to guarantee satisfactory QoS; enabling long-term development of the networks and services based on innovation and the development of the most efficient technical and business models; competition plays a fundamental role here, hence the importance of the regulatory authority objective of 'ensuring that there is no distortion or restriction of competition in the electronic communications sector, including the transmission of content'[27].

25 See Articles 9(2) \& 11(2) of the 1998 law on telecommunications.

${ }^{26}$ See Article 11(2).

${ }^{27}$ ITU (2017). Quality of service regulation manual, Regulatory and Market Environment, Telecommunication Development Sector, p.100.

\section{Principle of Convergence}

In the telecommunication domain in Cameroon, convergence is encouraged at every level, and the TRB plays a central role, to make sure that different networks interconnect, share infrastructure, including competition policies[28] This principle is not only limited to these issues, but extends to questions susceptible to disrupt the connectivity. In this respect, each operator must ensure the regular operation of its installations; permanent supply of services; adopt preventive measures of protection its installations against risk, threats, aggression, and whatever unforeseen danger; provide within reasonable time, the technical and human expertise needed to counter breakdown, and destruction in exceptional circumstances etc[29].

\section{Principle of Multiplicity of Service}

The presence of competition, consumer satisfaction, and the development of value-added services, is fundamental in the mobile telephony subsector [30]. This principle is one of the fundamental purposes of the telecommunication sector in Cameroon, which is to enhance the harmonious development of telecommunications networks and services with a view to ensuring the contribution of this sector to national economic development and satisfying the numerous needs of users and the population[31]. This principle extends to the obligation of not to limit access to the market or free competition from other enterprises; control production investments or technological progress, interoperability, objectivity and nondiscrimination [32].

To facilitate entry in the local exchange and multiplicity of services, entry in the retailing part of the telecommunications business should be encouraged, by requiring incumbent to sell to entrants at wholesale prices any retail service that they offer. Such entry is essentially limited to the retailing part of the market. The second and most significant novel way is through the leasing of unbundled network elements from incumbents. In particular, the incumbent should unbundle their networks and offer for lease to entrants network components (unbundled network elements) at prices 'based on cost' that 'may include a reasonable profit and be nondiscrirninatory. Thus it envisions the telecommunications network as a decentralized network of interconnected networks.

\footnotetext{
${ }^{28}$ Supra, 2.3 .

${ }^{29}$ See Article 15 of Décret No.2012/1638/PM du 14 Juin 2012, fixant les modalités d'établissement et/ou d'exploitation des réseaux et de fourniture des services des communications électroniques soumis au régime de l'autorisation.

${ }^{30}$ See Article 8.

${ }^{31}$ See article 1 of law $n^{\circ} 98 / 014$ of 14 July 1998 to govern Telecommunications in Cameroon.

${ }^{32}$ See Article 5(1).
} 


\section{Principle of Portability of Mobile Numbers}

Portability of numbers is the possibility for a consumer to use the same mobile number, independent of the operator or network operator to which he is registered, even in situations where he changes the operator or network operator [33]. The essentials of this principle is to the effect that the TRB shall establish and manage the numbering plan, and ensure equal and simple access by users to the different telecommunications networks and services, as well as the equivalence of numbering schemes [34]. This permits a particular user to identify himself to a particular network of his choice, relevant services as well as to access the network of other operators, in a transparent, objective and non-discriminatory manner[35].

Although the portability of telephone numbers is not yet operational, its planned commencement has been cancelled severally. First announced for the month of November 2016, then for 4 April 2017 by the Regulator of the telecommunications sector in Cameroon, the portability of numbers is still not effective to date. Yet, it concerns a measure that would allow service quality to subscribers to be improved, in so far as portability enables a subscriber dissatisfied with the quality of service offered by its original operator to migrate to a competitor deemed better, without having to change telephone number. According to the government daily, which cites a source in the Technical Committee implementing portability, "the absence of a framework of regulatory texts of this activity is a major difficulty which remains at this stage". On the technical level, we learn, the different telephone operators are ready at this time, in spite of delays observed in the deadline of 4 April in the training of their personnel or even in updating databases.

This project had passed a decisive stage on 31 January 2017 in Yaoundé, the Cameroonian capital, with the launch of activities of the Group of economic interest for the management of mobile portability in Cameroon (Groupement d'Intérêt Économique pour la Gestion de la Portabilité Mobile au Cameroun - GIE-

33 See Article 5(35) of Law No.2010/013 of 21 December 2010, regulating Electronic Communication in Cameroon. see the decree of application, Décret No.2012/1641/PM du 14 Juin 2012, fixant les conditions de portabilité des numéros des abonnés des opérateurs des réseaux des communication électroniques ouverts au public.

${ }^{34}$ See Article 31 law n ${ }^{\circ} 98$ / 014 of 14 July 1998 to govern Telecommunications in Cameroon. Equally see articles 49-50 of Law No.2010/013 of 21 December 2010, regulating Electronic Communication in Cameroon.

${ }^{35}$ See Article 32(1) of law n ${ }^{\circ} 98$ / 014 of 14 July 1998 to govern Telecommunications in Cameroon.
PMC), made up of the operators MTN, Orange and Nexttel. These three operators have been invited to invest a sum of FCfa 1.5 billion in the installation of a centralised database, in order to manage portability of mobile numbers in Cameroon. Since 2015, the contract for the provision, installation and operation of this infrastructure has been awarded by the Telecoms Regulator to Chinese equipment manufacturer Huawei. The timeframe of work had been limited to seven months.

\section{Principle of Non-discrimination and Equality of Services}

This principle provides that, after obtaining the necessary authorisation to operate telecommunications services in Cameroon, operators, must guarantee equality and non-discrimination in matters of pricing services offered to the public [36]. This principle applies especially with respect to high and low network concentration; geographical location of user etc. It covers the pricing obligation, suggesting that operators must make known to users their service offers, including value added services and their pricing [37]. This pricing obligation is subject to audit by the TRB, to ensure that the pricing is regular and sincere, and reflect the QoS offered [38]. Practically, this principle is challenged by a number of issues, for example, Camtel and TRB review a Reference Interconnection Offer (RIO) every year. SAT-3/WASC was included in the RIO for the first time in 2006. TRB attempts to use a cost-based approach, following the FL-LRIC model (Forward-Looking Long Run Incremental Costs) to determine fair pricing, but the regulator admits that all it can do is accept what Camtel is suggesting since the SAT-3/WASC shareholder agreement is secret and TRB has not seen it[39].

The principle of equality and nondiscrimination is further provided under the universal service obligations, numbering schemes, consumer protection, where there is the possibility everyone to be connected to public networks and to have access to basic telecommunications services; to benefit from other telecommunications services per the zone of coverage of each service; freedom of choice of telecommunications operator; equality of access to telecommunications services; and access to basic

\footnotetext{
${ }^{36}$ See Article 6 of Décret No.2012/1638/PM du 14 Juin 2012, fixant les modalités d'établissement et/ou d'exploitation des réseaux et de fourniture des services des communications électroniques soumis au régime de l'autorisation.

${ }^{37}$ See Article 8 \& 9.

${ }^{38}$ See Article 10.

39 Nzépa O. N. \& Keutchankeu R. T. (2012). 'Understanding what is Happening in ICT in Cameroon: A supply and Demand Side of the ICT Sector', Evidence for ICT Policy Action, Policy Paper 2, Research ICT Africa, p.36.
} 
information according to the conditions of coverage of telecommunications services and their pricing[40 ]. Equality of access and freedom of choice of telecommunications operators is fundamental, as no one can be denied the right to benefit from such services or forced to exploit a particular network. The enforcement of this principle is incumbent on the TRB, which has the power to ensure the respect for the equal treatment of users of all telecommunications enterprises [41]

In this respect, Article 5 of the 1998 telecommunications law clearly state that actions and practices which aim to, or may-prevent, restrict or compromise competition in the telecommunications market are prohibited, especially when they tend to:limit access to the market or free competition from other enterprises; - obstruct price fixing through the free intervention of market forces by artificially hiking or lowering them; - limit or control production investments or technological progress; - cut off markets or supply sources or create regional monopolies. This includes situations where an enterprise or group of enterprises is prohibited from making abusive use of: a dominant position on the local market or a good portion thereof; - a situation where a client or supplier without an equivalent solution is economically dependent on him. In this light, this principle holds that such abuses may consist, in particular, of 'unjustified discriminatory refusal of access to telecommunications networks open to the public or to the supply of telecommunications services, as well as unjustified or discriminatory discontinuance of established commercial relations' [42].

It is therefore incumbent on the TRB to 'comply with the principle of equality in the treatment of users in all telecommunications enterprises'. It is charged particularly to ensure that access to the networks open to the public takes place under objective, transparent and non-discriminatory conditions; guarantee sound and fair competition in the sector; draw up and manage the numbering plan, amongst others[ 43 ]. Specifically, in the domain of interconnectivity, article 27(1) of the 1998 Telecommunications Law states that 'operators of public networks shall grant, under conditions that are objective, transparent and non-discriminatory, all interconnection requests made by any operator of a public telecommunications service'. In the same light, with respect to numbering plan, article 32(1) holds that

\footnotetext{
${ }^{40}$ See Articles 27, $49 \& 52$ of Law No.2010/013 of 21 December 2010, regulating Electronic Communication in Cameroon.

${ }^{41}$ See Article 36(2).

${ }^{42}$ See Article 5(3) of law n 98 / 014 of 14 July 1998 to govern Telecommunications in Cameroon.

${ }^{43}$ See Article 22(2) of the 1998 law provides for the general responsibilities of the TRB in regulation and control of telecommunications activities in Cameroon.
}

the Board shall assign prefixes and numbers or sets of numbers to operators in a transparent, objective and non-discriminatory manner. Notwithstanding, the consequences is that any undertaking, agreement or contractual provision relating to a practice prohibited under section 5 of the 1998 telecommunications law, shall be null and void.

\section{Principle of Fair Competition in the Marketplace}

As far as completion principle is concerned, the law holds that network exploitation and the provision of telecommunications services must be carried out in a fair competitive environment. This principle is fundamental, as consecrated under article 5 of the 1998 law on telecommunications. The technical specifications on this principle include anti-trust subventions; illegal use of information obtained from competitor, for competition purposes; refusal to put at the disposal of an authorised operator, at the appropriate time, the relevant technical information on telecommunications installations, and pertinent commercial information necessary for supply of services[44]. The exigencies of transparency and nondiscrimination are substantial [45].

\section{The Principle of Consumers Protection}

The national policy on consumer protection is inspired by treaties, laws and regulations in force, notably the following principles: the principle of protection, according to which a consumer has the right of protection of life, health, security and environment, in their consumption of technologies, goods and services; the principle of satisfaction, according to which consumers have the right to basic satisfaction in the domains of health, food, energy, communication and technologies etc.; the principle of equity, according to which consumers have the right to full reparation for injury suffered, imputable to the supply of services, such as telecommunications; the principle of participation, according to which consumers have the right to found associations or consumer organisations for the protection of their rights[46].

In this respect, the TRB has the responsibility to protect consumers in their consumption of telecommunication services. To ensure such protection,

\footnotetext{
${ }^{44}$ See Article 4(3) of Décret No.2012/1638/PM du 14 Juin 2012, fixant les modalités d'établissement et/ou d'exploitation des réseaux et de fourniture des services des communications électroniques soumis au régime de l'autorisation.

${ }^{45}$ See Law $n^{\circ} 98 / 013$ of 14 July 1998 relating to competition in Cameroon.

${ }^{46}$ See Article 3 of Law N ${ }^{\circ} 2011 / 012$ of 06th May to lay down the framework of Consumer protection in Cameroon. Further see articles 4 et seq. equally see article 4 of Decree No.2013/0399/PM of February 27, 2013 fixing the modalities for the protection of consumers of telecommunications services.
} 
the TRB ensures the right of consumers in a contract of registration, whose model is previously validated by it [47]. This right conveys on the consumers, access to telecommunications services with adequate standards, quality and inherent regularity all over the national territory; freedom of choice and equality of access to telecommunications services; adequate information on telecommunications services; inviolability and communication secrets; non-disclosure of information about his identity; non suspension of services; reparation etc[48]. As such, consumers have the corresponding obligations to adequately use telecommunications services, equipment and network put at their disposal; respect for public property; and to report irregularities of telecommunications operators in their supply of services to the competent authorities etc[49].

\section{Obligations of Telecommunication Operators}

During telecommunications regulation, there are some fundamental obligations inherent to the regulators and operators, to ensure the fulfilment of the regulatory agenda, in the different regulatory agendas. These obligations are duties incumbent on these stakeholders, to facilitate activities in the regulatory environment.

\section{Universal Service Obligations}

According to the universal service obligation, every person has the right to benefit from telecommunications services, whatever their geographical location within the national territory [50]. This right consist of the possibility offered everyone to be connected to public networks and to have access to basic telecommunications services; to benefit from other telecommunications services per the zone of coverage of each service; freedom of choice of telecommunications operator; equality of access to telecommunications services; and access to basic information according to the conditions of coverage of telecommunications services and their pricing [51]. In this respect, operators have to ensure coverage of telecommunications services to all, both in terms of quality, affordability and continuity[52]. Also included in the universal service obligations, the possibility to have access or connect to public telephony, access to emergency services, possibility for certain groups to benefit from special measures, conveying of calls to and from registration points, toll free emergency calls,

\footnotetext{
${ }^{47}$ See Article 51 of Law No.2010/013 of 21 December 2010, regulating Electronic Communication in Cameroon.

${ }^{48}$ See Article 52(2).

${ }^{49}$ See Article 53.

${ }^{50}$ See Article 4 of Law No.2010/013 of 21 December 2010, regulating Electronic Communication in Cameroon.

${ }^{51}$ See Article 27.

${ }^{52}$ See Article 28(1).
}

supply of a free printed universal telephone directory and a free inquiry service, and all other activities in the telecommunications and information and communications technology sector deemed fit by the public authorities[53].

It is worth noting that the universal services are a dynamic concept, subject to amendments and periodic revision by the administration in charge of telecommunications [54]. Further, the financing of universal services is by the totality of users, and network operators, under conditions fixed by all parties [ 55 ]. On this note, article 23(1) of the 1998 telecommunications law states that a special telecommunications fund shall be set up within the TRB to finance the telecommunications universal service; and contribute to the financing of telecommunications development throughout the national territory.

However, one thing is certain, the law holds that a habitation area of at least 200 inhabitants must possess telecommunications services and that no person has to walk for more than three kilometres, to have access to such services[56]. In addition to routing emergency calls free of charge, it must be directed to the nearest public emergency services, including those responsible to serve lives, police and gendarmerie interventions, firefighting, social and civil protection services etc[57]. Concerning areas not covered by telecommunications network, the TRB identifies such areas, and undertakes measure for their coverage, including the selection of a proper service provider [58].

\section{Interconnection Obligations}

Interfaces for interconnecting traditional fixed telephony as well as mobile telephony are well established and all firms providing these services are typically directly or indirectly interconnected to all other networks. This ubiquitous interconnection is the result of a long historical process. Currently it is common to make ubiquitous interconnection a requirement in the license for telephone companies [59]. While interconnection is purely a matter of mutual

\footnotetext{
${ }^{53}$ See Article 28(2). Equally see article 18 of law $n^{\circ} 98$ / 014 of 14 July 1998 to govern Telecommunications in Cameroon.

${ }^{54}$ See Article 29(3).

${ }^{55}$ See Article 30 . Equally see article 18 of law $n^{\circ} 98 /$ 014 of 14 July 1998 to govern Telecommunications in Cameroon.

${ }^{56}$ See Article 8 of Décret No.2013/0398/PM du 27 Février 2013, fixant les modalités demis en œuvre du service universel et du développement des communications électroniques.

${ }^{57}$ See Article 10(1).

${ }^{58}$ See Articles $18-21 \& 28$.

${ }^{59}$ Hansen, B., (2003). 'Facility based competition in telecommunications: Three essays on two-way access
} 
agreement between interconnecting parties, any interconnect capacity creation, augmentation and/or disconnection of the interconnect capacity may have to be mutually agreed upon [60]. However, it is desirable for TRB to have ex-ante regulatory guidelines for establishing a proper environment to facilitate effective and expeditious interconnection in the interest of consumers. For this purpose, they may prescribe broad guidelines based on fair, reasonable and nondiscriminatory principles and leave the details of the interconnection agreement to be mutually decided by the interconnecting telecommunication operators (i.e. telecommunication service providers) in a time-bound manner. Alternatively, if they are unable to mutually agree upon terms and conditions of the interconnection agreement between themselves in a specified timeframe, a standard interconnection agreement which must be entered into between interconnecting telecommunication service providers may be prescribed.

\section{Quality of Service Obligation}

In this digital, globally connected world where all functions and aspects of life are being transferred to communication networks and services, citizens everywhere rely on ICTs to conduct their everyday socio-economic activities. Telecommunication networks are interconnected on a national, regional, and global basis, and the quality of telecommunication services applied in one network or one country influences the end-to-end quality of that service, so the quality cannot be considered only at national or regional level, but also needs to be considered globally [61]. Ensuring quality of service (QoS) in this ever-changing environment is increasingly critical, and an obligation inherent to all service operators [62]. A harmonised and common approach to regulating QoS would enable greater quality prospects irrespective of the locations of the consumer and service provider[63].

and one essay on three-way access', A dissertation submitted to BI Norwegian School of Management for the degree of Dr. Oecon, Series of Dissertations 5/2006, BI Norwegian School of Management Department of Economics, p.5.

${ }^{60}$ ITU (2017). Quality of service regulation manual, Regulatory and Market Environment, Telecommunication Development Sector, p.51.

61 See generally, ITU (2017). Quality of service regulation manual, Regulatory and Market Environment, Telecommunication Development Sector.

${ }^{62}$ See Article 9(2) of law n ${ }^{\circ} 98$ / 014 of 14 July 1998 to govern Telecommunications in Cameroon. See also Article 9(3) of Law No.2010/013 of 21 December 2010, regulating Electronic Communication in Cameroon.

${ }^{63}$ CEMAC draft directive No. /08-UEAC-133-CM-18, Fixant le Cadre juridique de la protection des droits des utilisateurs de réseaux et de services de communications électroniques au sein de la CEMAC,
QoS obligation cannot be discussed in isolation from Quality of Experience (QoE) and network performance. According to ITU-T Recommendation P.10/G.100, quality of experience (QoE) was initially defined as the overall acceptability of an application or service, as perceived subjectively by the end-user. In fact, Quality of experience (QoE) is the degree of delight or annoyance of the user of an application or service [64]. QoE includes complete endto-end system effects (end-user equipment, as well as network and service infrastructure). Overall acceptability may be influenced by user expectations and the context. QoE takes into account additional parameters: user expectations; user context (e.g. personal mood, environment, work/home/outside, etc.); potential discrepancy between the service offered and individual user awareness of the service and additional features (if any) for that service. It is on these grounds that the TRB has the power to periodically adapt and fix minimal quality for universal service coverage [65]. As such, the administration in charge of telecommunications, periodically reviews the content of the universal service, taking into consideration technological advancements, market situation, social and economic considerations relevant for the general interest[66].

One may conclude that QoE is different from QoS as it is based on customer perception of the given service. QoE includes the complete end-to-end system elements (client, terminal, network, services infrastructure, etc.) and may be influenced by user expectations and context. In principle, QoE is measured subjectively by the end-user and may differ from one user to another [67]. On its own part, network performance is determined by the performances of network elements one by one, or by the performance of the network as a whole, i.e. the combination of the performance of all single elements. However, network performance has an influence on QoS, and it represents a part of it. Simply said, QoS consists of network performance and non-network performance [68]. In Cameroon, network performance issues are directly linked to QoS exigencies and dependent on operators, for proper implementation [69]. The TRB carries out

adequately treats QoS issues with respect to coherence, permanence, unwanted calls, contracts, billing, etc.

${ }^{64}$ ITU (2017). Op. Cit., p.12.

${ }^{65}$ See article 3(2) of Décret No.2013/0398/PM du 27 Février 2013, fixant les modalités demis en œuvre du service universel et du développement des communications électroniques.

${ }^{66}$ See Article 2(2).

${ }^{67}$ Ibid.

${ }^{68}$ ITU (2017). Op. Cit., p.13.

${ }^{69}$ See article 6(2) of Décret No.2013/0398/PM du 27 Février 2013, fixant les modalités demis en œuvre du service universel et du développement des communications électroniques. 
regular findings on network performance, and suggest proper action. For example, with respect to interconnection quality, the indicators used are as follows: the number and duration of disruption of interconnection; the speed of reestablishment of interconnection link; the level of efficiency of services using interconnection; the level of blockage and interruptions for origin and termination services etc[70].

In the Cameroonian context, the TRB and the NAICT are each charged with the enforcement of QoS[71] because of the technical details involved, given the consumer vulnerability. They have the primordial role of setting and enforcing quality standards. Enforcement mechanisms of quality of service include the following:

- Reports of QoS submitted monthly or quarterly by telecommunication operators to the regulator (may Include technical and non-technical parameters);

- QoS monitoring tools for auditing;

- Penalties and disincentives;

- Independent customer surveys and their publication [72].

\section{Infrastructure Sharing in Mobile Obligations}

Given that infrastructures of the public telecommunications network, established on State property, are used for the development and operation of public networks and for providing any telecommunications service to the public, it is a fundamental obligation for all operators to use such properties[73]. The exigency here is that the sharing of infrastructure cannot be denied by an operator, except there are good reasons for such refusal; where there is good cause fore disruption or any other technical difficulty with regard to the proper establishment of the network and smooth operation of the service[74].

${ }^{70}$ See article 4 of Décret No.2012/1640/PM du 14 Juin
2012 , fixant les conditions d'interconnexion, d'accès
aux réseaux de communications électroniques ouverts
au public et de partage des infrastructures.
${ }^{71}$ See articles $14-18$ of Decree No.2013/0399/PM of
February 27, 2013 fixing the modalities for the
protection of consumers of telecommunications
services.
${ }^{72}$ See article $4(3)$ of Décret No.2012/1640/PM du 14
Juin 2012, fixant les conditions d'interconnexion,
d'accès aux réseaux de communications électroniques
ouverts au public et de partage des infrastructures.
${ }^{73}$ See Article 29 of law ${ }^{\circ} 98 / 014$ of 14 July 1998 to
govern Telecommunications in Cameroon. Equally see
article 45 of Law No.2010/013 of 21 December 2010 ,
regulating Electronic Communication in Cameroon.
${ }^{74}$ See Article $30(3)$ of law ${ }^{\circ} 98 / 014$ of 14 July 1998 to
govern Telecommunications in Cameroon. Equally see
article $46(3)$ of Law No. $2010 / 013$ of 21 December
2010 , regulating Electronic Communication in
Cameroon. see generally articles 50 et seq. of Décret

\section{Compliance with Licence Obligations}

Compliance with licencing obligations is greatly regulated by two decrees of applications: one on the authorisation regime and another on the declaration regime [ 75 ]. The general rule is that they are consecrated on the principles of technology neutrality, convergence, and multiplicity of services, interoperability, and competition [76]. The terms and conditions for telecommunication operators authorised to set up a public network contain obligations of a general nature, such as: minimum coverage of the population or the territory; a minimum number of services offered to consumers and a minimum quality threshold; guaranteed protection of personal data and the private lives of users and secure electronic exchanges. The focus here is on all of the relevant frequency bands and licence types simultaneously in order to assess the Mobile Network Operators' (MNO) compliance with the obligations of their respective licences. The MNOs that currently hold licences in Cameroon are: MTN, Orange, Nexttel and Camtel.

The issue is on how the individual MNOs networks perform in relation to each of its licence conditions at every point in time. Licence Coverage, represents the ability to place a call at a specific location at a specific time using a standard handset. Given the differing performance of telephones or other types of terminals, including other variables that can affect end-user experience, the coverage at every time cannot always be equated to end-user experience. Some other factors currently affecting end-user experience of mobile phones and hence licence obligations are: the increased use of phones with poorer antenna performance; changing consumer habit (e.g. increased use of data, greater reliance on phone) and expectations; the integration of new services into mobile networks (e.g. $3 \mathrm{G}$ and $4 \mathrm{G}$ ); and the ability of mobile phone operators to find suitable sites or obtain planning permissions. All digital modulation schemes are reliant on a minimum Signal to Noise Ratio ("SNR") and the

No.2012/1640/PM du 14 Juin 2012, fixant les conditions d'interconnexion, d'accès aux réseaux de communications électroniques ouverts au public et de partage des infrastructures.

${ }^{75}$ See Décret No.2012/1638/PM du 14 Juin 2012, fixant les modalités d'établissement et/ou d'exploitation des réseaux et de fourniture des services des communications électroniques soumis au régime de l'autorisation and Décret No.2012/1639/PM du 14 juin 2012, fixant les modalités de déclaration, ainsi que les conditions d'exploitation des réseaux et installations soumis au régime de la déclaration.

${ }^{76}$ See Article 4(1) of Décret No.2012/1638/PM du 14 Juin 2012, fixant les modalités d'établissement et/ou d'exploitation des réseaux et de fourniture des services des communications électroniques soumis au régime de l'autorisation. 
higher the data throughput the greater the SNR required [77].

\section{The regulatory structures of telecommunication sector in cameroon}

Regulation takes different structures, based on the institutional and organisational approaches. More importantly, the national regulatory authorities work in collaboration with other international bodies, in the telecommunications domain. This section reviews the regulatory structure in Cameroon and the competences.

\section{International bodies/Organisations in Mobile Telecommunication Sector in Cameroon}

Most of the regions in the world have initiated regulations in form of telecom policies, laws and acts to invite participation from foreign and domestic players to put an end to monopoly. Establishment of independent regulator has created a level playing field for the new players among the established incumbents and protecting their interest by promoting healthy competition and reducing the SMP of incumbents. Privatization has benefitted the subscribers with improved services and faster deployments of nextgeneration networks in the sector. To achieve full globalization in terms of connectivity, several international bodies had played a significant role in establishing standards that enabled international roaming. This section gives you a brief of several organizations and associations who have contributed significantly to the welfare and growth of telecom industry. ITU plays a key role in maintaining the numbering system, recommending ideal radio frequencies for different technologies, assessing future requirements for telecom growth and collaborating for the development of new-generation technological standards[78].

\section{World Trade Organization (WTO)}

Created in 1994 as a result of the Uruguay Round of the General Agreement on Tariffs and Trade (GATT), the World Trade Organization (WTO) is a global international trade organization that develops international commerce rules and mediates trade disputes among its members. The WTO brings together 148 members [79] that participate in negotiations and

77 See Commission for Communications Regulation (2016). 'Assessment of Mobile Network Operators' Compliance with Licence Obligations (Coverage)', Information Notice: ComReg 16/113, pp.6-7.

78 Business Monitor International (2013). Indonesia telecommunications report $\quad$ Q1 2013. Availableat:http://www.researchandmarkets.com/report s/2355075/. 'Accessed on 6 September 2017).

${ }^{79}$ As of February 2005, the WTO was comprised of 148 members. The list of members and their respective dates of accession may be found at http://www.wto.org/english/thewto_e/whatis_e/tif_e/org 6_e.htm. binding commitments concerning the promotion of competition and the liberalization of international trade of goods and services [80].

Concluded in 1997 under the auspices of the WTO, the Fourth Protocol to the General Agreement on Trade in Services (GATS) represents one of the major steps towards liberalization of the global telecommunications marketplace and the establishment of liberalization [81]. The purpose of GATS is to facilitate liberalization of trade in services. Studies show that since 1997, countries that made GATS commitments have experienced faster levels of fixedline penetration, mobile subscribership, and telecommunications sector revenues. In particular, lowincome Sub-Saharan Africa countries that have scheduled commitments out-performed those that did not [82]

The Agreement BTA established the basis for structural reform of the telecommunications sector aimed at removing barriers to entry and competition, and the adoption by the majority of members of certain pro-competitive regulatory principles that are set out in the 'Reference Paper on Regulatory Principles'. These telecommunications commitments apply to basic telecommunications and certain value-added services, but not to audiovisual service [83].

\section{International Telecommunication Union (ITU)}

ITU is the United Nations specialized agency for Information and Communication TechnologiesICTs. Created in May 1865, this body consists of 193 member States and more than 700 independent private sector partners and Universities. It's headquarter is in Switzerland- Geneva and counts 12 regional offices around the globe.

\footnotetext{
${ }^{80}$ International Telecommunication Union (ITU), ICT Regulation Toolkit, Module 6. Legal and Institutional Framework, p.21.

81 Nihoul, P.L.G.(2004). 'Audiovisual and telecommunications services: a review of definitions under WTO law,' in Geradin, D. \& Luff, D. (eds). The WTO and Global Convergence in Telecommunications and Audiovisual Services, p.362.

${ }^{82}$ International Telecommunication Union (ITU), Op. Cit., p.21. Equally see the Analysys and Harris, Wiltshire \& Grannis, (2004). Telecommunications Trade Liberalization and the WTO, Final Report for the World Bank, p.1.

${ }^{83}$ To date, 105 of the 148 WTO members have made commitments under the BTA. Ninety-eight WTO members have made specific commitments on basic telecommunications and 89 members with respect to valueadded telecommunications services. GATS Fourth Protocol, the Reference Paper is available at http://www.wto.org/english/tratop_e/serv_e/telecom_e/t el23_e.htm.
} 
The agency works towards international cooperation between the Governments and private sector. ITU organises its activities among various study groups which are part of the three main focus areas (radio communications, standardization and development). ITU provides a platform for exchange of knowledge among the stakeholders which help in development of ICT sector. As a member of United Nations Development Group, ITU is committed to the development of ICT sector by establishing a platform for exchange of knowledge and international cooperation among various stakeholders in this sector. One of the significant works ITU performed was in the area of international radio frequency administration. The regulations regarding the international radio frequency are being approved by all the ITU member states. ITU-T is committed in development of standards for newer technologies in this sector and one of the focus groups (IMT-2020) is currently working on network standardization requirements for 5G. ITU-D aims at sustainable development and to spread equitable and affordable access for social and economic development. Another landmark activity undertaken by ITU was in drafting the "International Telecommunication Regulations (ITRs)"with document on final acts being presented at World Administrative Telegraph and Telephone Conference (WATTC). ITRs discuss the telecommunications service rules operating at international borders with the aim of promoting global connectivity [84].

The ITU targets a continuous, sure, strong and evolutive network coverage. It is responsible for the management of the International Frequency Registration Board (IFRB). Away from norms and frequency attribution, the Union caters for the following technical aspects:

- Definitions, symbols and classifications;

- General statistics on telecommunications;

- General operations on networks, telephone services, service operators and human factors; E.123denoting national and international telephone numbering and electronic addresses, E.164-being the numbering plan for mobile telephones; supplement $\mathrm{N}^{\circ} 2$ being portability.

- Non telephone telecommunications services;

- Transmission and media systems, numeric and network systems,

- Numeric network and systems integration (RNIS);

- Multimedia signals;

- Protection against interferences;

- Constitution, installation, protection of cables and other external installation elements;

$84 \quad$ ITU (2013) Statistics. Available at:http://www.itu.int/ITU-D/ict/statistics/. (Accessed 28 May 2017).
- Network maintenance, international transmission systems, telephone circuits, etc.

- Quality of transmissions and signals;

- Internet protocol;

- Languages and software analyses and choice for communication systems etc.

Cameroon has always been present and active in regional and international telecommunication organizations. It is a member of the Administrative Councils of both the African Telecommunication Union (ATU) and the International Telecommunication Union (ITU). It has had very few bilateral exchanges of experience and information with other African countries [85].

\section{National Regulatory Structures of Telecommunication Sector in Cameroon}

A number of institutions are involved in the control and development of telephony and ICTs in Cameroon. The government has general oversight of the development and control process, but there are also dedicated institutions; both national and international, including national and international organisations.

\section{Ministry of Posts and Telecommunications}

The administration in charge of telecommunications activities in Cameroon is the ministry of Posts and Telecommunications established at independence. Up till the late 80s, the telecommunication industry in Cameroon was the exclusive preserve of the State. The State assumed the sole responsibility of provider. There was little or no concern about regulating may be, because the state presumed it was doing 'just the right thing'. The state could supply limited services to a limited population with the available resources at the time under the auspices of the Ministry of Post and Telecommunication (MINPOSTEL), with their main products being postal services and fixed telephone services. But as the 80 s phased out, the 90 s ushered in strong globalisation trends. Ensnared by the goodies of globalisation and its tantalising offers, both the state and its citizens yearned to join in the trend. There was pressure and every reason for expansion, resulting in the establishment of three key actors [86] in the telecommunication industry in Cameroon. These included the administration, charged with adopting national policies and general supervision of the sector, the Telecommunication Regulation Agency [ 87 ],

\footnotetext{
${ }^{85}$ International Telecommunication Union, (May 2001). 'Telecommunication Sector Reform: Cameroon's Experience', Africa Regional Preparatory Meeting for the World Telecommunication Development

Conference (WTDC-02), Yaounde (Cameroon), p. 6. ${ }^{86}$ See Law no.98/014 of $14^{\text {th }}$ Jan. 1998 .

${ }^{87}$ L'Argence de Regulation des Telecommunications (ART).
} 
charged with regulation and control of the activities of operators [88] within the sector and the various operators who ensure that their operations conformed to the rules and regulations in force.

According to article 21 of the 1998 Telecommunication Law, the Administration in charge of telecommunications is responsible for the formulation and implementation of a sectorial telecommunications policy, taking into account the technological advances in the telecommunications sector, the development needs and the Government priorities in the area of telecommunications. Such policy is essentially geared towards coping with the gradual changes in the market structure, especially by providing for an adequate number of operators in each sector of the market. This authority is also charged to ensure the implementation of this policy and compliance with the regulations relating thereto. In addition to these responsibilities, it is responsible for: the supervision of the telecommunications sector; supervision of public telecommunications enterprises; representation of the State in international organisations and events concerning telecommunications; and formally issuing to operators and other service providers, after approval by the Regulating Board, authorisations, as well as declarations and approval receipts for networks open to the public and vocal telephony services [89].

\section{Cameroon Telecommunications Corporation (CAMTEL)}

Cameroons first international telecommunications business was done by the International Telecommunications Corporation of Cameroon, commonly known and called by its French acronym INTELCAM. It was created by law n ${ }^{\circ} 82-539$ of 28 October 1982. While this state corporation managed international telecommunications activities, the agency for the commercialisation of telecommunications (ACTEL) was created alongside to take care of the internal telecommunications network. One month after INTELCAM was set up; another law came in rather swiftly to grant monopoly for it to operate all submarine, terrestrial and spatial radio waves, telecommunications systems, international transit centres required for the routing of international telephone, telex and telegraph traffic and transmission of data, facsimiles, and sound and television pictures. This is law n ${ }^{\circ} 82-17$ of 26 November 1982. With this monopoly in place, the client was to lose his kingship for more than one and one half decades until Decree No.98/198 of September 8, 1998, on the Creation of Cameroon Telecommunication Corporation, created

88 In this case the main operators in the telecommunication industry in Cameroon include multinational enterprises such as MTN and Orange Cameroon

${ }^{89}$ See Article 21(2).
Cameroon Telecommunications Corporation (CAMTEL) to succeed INTELCAM. This is in line with the provisions of Law No 98/014 of 13 July 1998 to govern Telecommunications in Cameroon, which opened up the telecommunication sector to competition, by allowing both foreign and national companies to provide telecommunications services [90].

In this perspective, two public enterprises, CAMTEL for the fixed telephone service and CAMTEL Mobile for the mobile telephone service, were set up to take over the telecommunication activities of the Ministry of Post and Telecommunications and of the public enterprise INTELCAM, which was in charge of operating and developing international telecommunication installations. Immediately after, the sale of a mobile telephone license and the process of privatising CAMTEL and CAMTEL Mobile got under way[91].

CAMTEL was created in line with the law regulating the general status of public and semi-public enterprises [92]. It was granted a legal personality and a financial autonomy, and even the power to create subsidiaries [ 93 ]. CAMTEL has as objectives, to operate and supply telecommunication services and infrastructures, in accordance to the prescription of the licence issued to her by the competent authority. To this effect, CAMTEL has the monopoly to ensure the carrying out of feasibility studies, installation, exploitation, and maintenance of all systems necessary for the supply of telecommunications services all over the national territory; including the connection of the local or national networks to the international networks [94]. Its management structure is made up of two organs: the Board of Directors and the General Manager [95]. It is worth noting that CAMTEL was set up at the same time with the Telecommunication Regulatory Agency.

\section{Telecommunications Regulatory Board (TRB)}

Well known by its French acronym 'Agence de Regulation des Telecommunications' (ART), the setting up of an independent regulatory body, TRB, encouraged the liberalisation of the telecommunication sector in Cameroon. Law 98/014 governing telecommunications in Cameroon establishes the Telecommunication Regulatory Agency to apply rules

\footnotetext{
${ }^{90}$ See Article 2(1).

${ }^{91}$ International Telecommunication Union, (May 2001), Op. Cit., p.3.

${ }^{92}$ See Law No.99/16 of December 22, 1999, on the general status of public establishments, public and semi-public enterprises.

${ }^{93}$ See Article 1 of Decree No.98/198 of September 8, 1998, on the Creation of Cameroon Telecommunication Corporation.

${ }^{94}$ See Article 2.

${ }^{95}$ See Article 5
} 
and supervise operators, by regulating, controlling and following up the activities of businesses and operators involved in the telecommunications sector, and particularly ensuring compliance with the principle of equality in the treatment of users in all telecommunications enterprises[96].

After the telecommunications liberation with the 1998 law, came Decree No.98/197/R of September 8, 1998 Laying down the Organisation and Functioning of the Telecommunications Regulatory Board [97]. In its capacity, the Board is especially responsible for: Ensuring the implementation of legal and statutory texts governing telecommunications; Ensuring that access to public networks is provided under objective, transparent and non-discriminatory conditions; Guaranteeing sound and fair competition in the telecommunications sector; Defining the principle which should govern the fixing of rates for services provided; Studying applications for authorisation and declaration, and preparing documents and publishing invitations to tender for concessions, in accordance with the legal and statutory provisions in force; Defining the conditions and obligations relating to interconnection and sharing of infrastructure; Managing the frequency spectrum of the telecommunications sector, notably the allocation and control of the frequencies of the said sector; Designing and managing a numbering plan; Submitting to the government any proposal or recommendation which aims at developing and modernising the telecommunications sector; Studying homologation documents for terminal equipment and preparing decisions related thereto; Carrying out any mission of general interest which may be entrusted to it by the government in the telecommunications sector; and Giving an opinion on draft legal and statutory instruments governing telecommunications[98].

In addition, Article 21(1) of the 1988 Law stipulate that, the Administration in charge of telecommunications shall be responsible for the formulation and implementation of a sectorial telecommunications policy, taking into accounts the technological advances in the telecommunications sector, the development needs and the Government priorities in the area of telecommunications. Such policy shall be essentially geared towards coping with the gradual changes in the market structure, especially by providing for an adequate number of operators in each sector of the market. The Administration in charge of telecommunications shall also ensure the implementation of this policy and compliance with the regulations relating thereto. According to article 21(2),

${ }^{96}$ See Article 22.

97 This law was further amended by Decree No.2012/203 of April 20, 2012, on the Organisation and Functioning of the Telecommunications Regulatory Board.

${ }^{98}$ See Article 22(2). the Administration in charge of telecommunications shall, in addition, be responsible for: - supervising the telecommunications sector; - supervising public telecommunications enterprises; - representing the State in international organizations and events concerning telecommunications; - formally issuing to operators and other service providers, after approval by the Regulating Board, authorizations, as well as declarations and approval receipts for networks open to the public and vocal telephony services;

The Cameroon Telecommunications Regulatory Agency finds itself in the midst of three converging forces notably:

- The Government of the Republic which has the herculean task of applying laws and rules in force.

- The operators and exploiters of telecommunications networks; they are the ones investing with the view of developing the sector and making profits while providing vital communications services in the country.

- The consumers of the products and services offered by telecommunications operators; they are the final users.

The cardinal missions of the regulator within the framework of consumer protection are declined under article 22 of the 1988 Law which governs telecommunication in Cameroon as follows: The Board is responsible for regulating, controlling and following up the activities of businesses and operators involved in the telecommunications sector, to wit:

- The control of the quality of service: The regulator sees to it that the emission and reception from homologated terminals are of the best possible quality and do not cause any nuisance or harm to the users.

- The control of tariffs: Here the regulator is charged with verifying that tariffs are intricately linked to costs of production and that the profit margins are not excessive or abusive.

- The treatment of Consumer complaints: The Telecommunications Regulatory Agency has the duty to verify that the fixing and correction of faults and malfunctions are done within reasonable time and in case of overbilling of airtime attribution failures, solutions are provided adequately.

- The availability of services ought to be available on the whole zone covered by the different networks and in the quality and diversity required [99].

\footnotetext{
${ }^{99}$ See Section 22(2) of the law which is to the effect that The Board shall be responsible for regulating,controlling and following up the activities of businesses and operators involved in the telecommunicationssector. It shall also ensure 
The Board is also responsible for settling disputes between operators, especially as concerns interconnection or access to the telecommunications network, numbering, frequency interference and the sharing of infrastructure[100]. So far the Board has authorised three mobile telephone networks to operate in Cameroon, to wit: Société Camerounaise de Mobile, now Orange, Mobile Telecommunications Network (MTN) and Nexttel. Contrariwise, it is worth reiterating that operating licences are issued by the Minister in charge of Telecommunications, on a proposal from the Regulatory Agency, according to a decree fixing the procedures for establishing or operating networks and providing electronic communication services subject to a licencing scheme. This government text thus seems to vindicate the administration in charge of Post and Telecommunication, criticising the Telecommunications Regulatory Authority (Agence de Régulation des Télécommunications - ART), for illegally granting itself the issuance of "temporary permits" to telecom companies subject to licencing.

In a communiqué published in January 2017, the boss of Telecoms gave operators holding "temporary permits" issued by ART up to last 14 February to comply with the law, at the risk of losing their right to do business on Cameroonian territory. According to our findings 22 operators are concerned by this warning from the Minister in charge of Telecommunications, namely Créolink, Ringo Sarl, Northwave Sarl (Vodafone), Global Solutions Technologies, CFAO Technologies, Digitel Sarl, Decsite Africa Sarl, GTS Infotel, Green Tech, Avilyos, TNT Africa, Afrikanet Online, Matrix Telecom, Easynet SA, Seme Telecom, Sphere 3i, HTT Telecom, etc[101]. More than a month after the deadline fixed by the Minister of Post and Telecommunications expired for these operators (14 February 2017), a decree was signed on 6 April by the Prime Minister grants a new extension of 6 months to allow these companies to comply with current regulation.

Unfortunately, as is the case before the reform of 2010, the new government text once again remains silent on the amount of the fee to be paid to the State by telecoms operators subject to licencing. It is into this gap that ART stepped, when the fee with collection methods and amount unknown until now, and started to issue "temporary permits" to operators disregarding regulatory measures.

compliance with the principle of equality in the treatment of users in all telecommunications enterprises ${ }^{100}$ See Article 22(3).

101 'PM partially settles dispute between Minpostel and ART on granting licences to telecom companies', in Business in Cameroon, Magazine, No.15, (May 2017).
National Agency for Information and Communication Technologies (NAICT)

The National Agency for Information and Communication Technologies (NAICT), or Agence nationale des technologies de l'information et de la communication (ANTIC), was created by Decree $\mathrm{n}^{\circ} 2012 / 180$ of 10 April 2012 on the organisation and functioning of the National Agency for Information and Communication Technologies (ANTIC). It has as mission to promote and follow up state policies in the domain of information and telecommunication technologies; regulation, control and follow up of activities linked to security systems in the information and electronic communication networks, including electronic certification in collaboration with the Telecommunication Regulation Board[ 102 ]. It is responsible for harmonising technical standards, providing design and development expertise to government ministries, coordinating establishment and monitoring of public-sector Internet, intranet, and extranet sites, contributing to technical training of instructors for universities, colleges, secondary, and primary schools, and training public-sector personnel.

In a nutshell, the NAICT is now the governmental watchdog for activities related to the security of electronic communication networks in accordance with cyber-security and cybercrime law.

\section{The Competition and Consumer Protection Associations}

These are advocacy groups that seek to protect people from corporate abuse like unsafe products, false advertising, and pollution. Consumer organizations may operate via protests, litigation, campaigning, or lobbying. They may set themselves up as more general consumer watchdogs. The aim of consumer organizations may be to establish and to attempt to enforce consumer rights. Effective work has also been done, however, simply by using the threat of bad publicity to keep companies' focus on the consumers' point of view. Consumer organizations may attempt to serve consumer interests by relatively direct actions such as creating and/or disseminating market information, and prohibiting specific acts or practices, or by promoting competitive forces in the markets which directly or indirectly affect consumers such as electricity, communications, etc[103].

The continuous abuse of customers' rights by mobile operators in Cameroon may be partly due to the

${ }^{102}$ See Article 4 of Decree ${ }^{\circ} 2012 / 180$ of 10 April 2012 on the organisation and functioning of the National Agency for Information and Communication Technologies (ANTIC).

${ }^{103}$ Consumer organization, From Wikipedia, the free encyclopedia, available at: http://en.wikipedia.org/wiki/article:Consumer_organizat ion, (Last Accessed 20 March 2017). 
fact that customers do not know where to take their grievance. Civil society organizations in the domain of ICT have as one of their missions, to protect to help the vulnerable customers enforce their rights. Here is a List of consumer protection associations which may be of help to vulnerable customers: Association Camerounaise Des Consommateurs Des Télécommunications et TIC (ACTIC), African civil society for the information (ACSIS), Association des consommateurs $d u$ septentrion, Association-douze millions de consommateurs (ADMC), Association pour la défense des consommateurs, Association pour la défense des consommateurs (ADPC), Bureau national pour la protection des consommateurs (BNPC), CEDACAM, CEFEPROD, Cercle des consommateurs du Cameroun, Chambre nationale des consommateurs (CNACOC), CIC, Défense des Droits de l'homme et des consommateurs du Sahel (DHCS), Front National des Consommateurs du Cameroun, Groupement national de défense des droits des consommateurs (GNDDC), Ligue camerounaise des consommateurs (LCC), Mission Charité, Mouvement National des Consommateurs, Mutuelle de défense des droits consommateur et de l'environnement, Organisation pour la protection des Droits et des Intérêts Humains (OPDIH), Organisation for consumer Sovereignty (OCOSO), Union des Consommateurs Camerounais (UCOCAM), VIGIE patrie.

\section{Dispute resolution and enforcement mechanisms in the telecommunication sector in cameroon}

Dispute resolution regulations generally include procedures for handling and resolving disputes between: licensees and consumers; licensees, and the regulator and investors, operators or service providers. As the telecommunications sector develops and matures, the ability of the regulator to maintain order in the sector is paramount to promoting growth and attracting investment in the sector. Because of the impacts of privatisation, liberalisation, and convergence, it is increasingly important for Cameroon and her regulators to have an effective and efficient dispute resolution system. General perspective holds that failure to resolve disputes quickly can limit competition, cause delays in the introduction of new services and infrastructures, block or reduce investment in the sector, and impede liberalisation and development of the sector[104]. In most countries, for example, the general business culture is fundamental in this respect.

\section{Dispute resolution}

The role in Cameroon is that the administration in charge of telecommunications (MINPOSTEL) is the competent authority to ensure the

\footnotetext{
${ }^{104}$ Robert R. B., et al., (2004), 'Dispute Resolution in the Telecommunications Sector: Current Practices and Future Directions, World Bank/International
} Telecommunication Union Report, p.v. implementation of State's telecommunications policy and compliance thereof [105]. The TRB on its part is responsible for regulating, controlling and following up the activities of businesses and operators involved in the telecommunications sector [106]. Most importantly, the law states that the TRB 'shall arbitrate in the event of disputes between operators concerning in particular, the interconnection or the access to a telecommunications network, numbering, frequency disturbance and the sharing of infrastructure'[107]. The TRB has the power to give its ruling within a period of one month after the matter has been referred to it, notwithstanding the fact that the TRB's ruling can be contested by one of the parties. In such circumstances, the TRB shall immediately designate one or more arbitrators, inform the parties in conflict and give them a time-limit within which to plead their cases. In case one of the parties seizes the competent legal authority, members of the TRB can be heard as expert witnesses.

In this light, the 2010 law on electronic communications in Cameroon emphasises that the TRB is the competent authority to acknowledge at first instance, a dispute between any operators of electronic communications networks, relating to issues of interconnection and sharing of infrastructure, frequency interference, numbering plan, access requirements etc.[108]. It is important to point that interconnection disputes are the most prevalent type of disputes between service providers, as operators of all different types of access networks (e.g., fixed-mobile, wire line-wireless) must be able to interconnect with each another. There is the need to maintain some form of regulatory oversight of the negotiation and implementation of interconnection arrangements between the mobile telephony operators in Cameroon. What is prevalent in Cameroon is an increasing issue regarding mobile interconnection, where most often, high rates are charged by mobile providers to terminate traffic on their networks.

The law provides the TRB with a dispute resolution organ, which can invite both internal and external experts, when need arises [109]. The TRB has a conciliation mission, as between the parties, which can resolve to court action in case of non-conciliation [110]. Most importantly, in case the dispute is of a nature to perturb telecommunication services, the TRB can take and implement temporary measures to ensure

\footnotetext{
${ }^{105}$ See Article 21 of Law n ${ }^{\circ} .98$ / 014 of 14 July 1998 to govern Telecommunications in Cameroon.

${ }^{106}$ See Article 22 (2).

${ }^{107}$ See Article 22 (3) \& 37 et seq.

108 See Article 65(1) of Law No.2010/013 of 21

December 2010, regulating Electronic Communication in Cameroon.

${ }^{109}$ See Article 65(3) \& (4).

${ }^{110}$ See Article 65(6)
} 
the continuity of the network services[111]. On another note, a sentence can be suspended, if it is discovered that its execution will lead to gross injustice and illegality [112]. Further, the TRB as of right, or through the demand of the Administration in charge of telecommunications, or a professional association or duly registered association, or a moral or physical person, bring an action before the TRB[113]. The 1998 telecommunications law states that:

'the TRB as of right or at the request of the administration in charge of telecommunications, a professional organization, an approved association of users or a natural person or corporate body concerned, after observation or verification, penalize any default by network operators or suppliers of telecommunications services, in accordance with the provisions of the laws and regulations relating to their activity or with decisions taken to ensure implementation thereof'. 114

In fact, the framework law on consumer protection provides under article 26 (1) that the defence of the interest of a consumer or group of consumers can be done in court or before any arbitration body [115]. In this case, the TRB is the competent authority when it comes to issues of electronic communications. The consumer or his successor or consumer group can lodge the complaint before the TRB for preventive or remedial purposes [116]. Disputes between service providers and consumers principally stem from the consumer's lack of bargaining power or the absence of competitive options to the incumbent operator. The main type of disputes arising between consumers and service providers derive from the following causes: service charges; billing; payment of charges; slamming; quality and terms of service; violation of privacy; and false or deceptive advertising [117].

\footnotetext{
${ }^{111}$ See Article 65(10). Equally see article 45 of Law ${ }^{\circ}$ 98/014 of 14 July 1998 to govern Telecommunications in Cameroon.

${ }^{112}$ See Article 65(12).

${ }^{113}$ See Article 66 of Law No.2010/013 of 21 December 2010, regulating Electronic Communication in Cameroon. Equally see 21 of Décret No.2013/0399/PM du 27 Février 2013, fixant les modalités de protections des consommateurs des service de communications électroniques.

${ }^{114}$ See Article 39 of Law n ${ }^{\circ} 98$ / 014 of 14 July 1998 to govern Telecommunications in Cameroon.

${ }^{115}$ See Law No. 2011/012 of 6 Nov 2011, framework on consumer protection in Cameroon.

${ }^{116}$ See Article 27.

${ }^{117}$ International Telecommunication Union (ITU), $O p$.
} Cit., p.165.

\section{Enforcement Mechanisms in Mobile \\ Telecommunication Sector in Cameroon}

The regulator must be given sufficient power to enforce telecommunications laws and regulations, and must have the ability not only to enforce rules of general applicability, but also to issue directions and mandate operators to carry out or to stop a particular activity. The TRB's enforcement power is guaranteed under article 5, where it has the power to make pronouncements in accordance to the rules and regulations in force [118]. The differences in market and regulatory maturity, as well as legal and judicial practices, affect the enforcement practices and procedures of individual countries [119]. However, it is generally agreed that an effective enforcement system is essential in any economy in order to give effect to those rules necessary for maintaining order in the sector, maintaining and facilitating stability, growth and development of the sector, deterring wrongdoing, protecting consumers, and maximising social and corporate welfare[120].

The Telecommunications Regulatory Board (TRB) of Cameroon provides a good example of the necessary tools that regulators must have to carry out their responsibilities of enforcement. In accordance to article 41 of the 1998 telecommunications law, if an offence is duly established by the TRB, it shall give the offending operator notice to comply with the provisions of the laws and regulations or with the prescriptions of the license under which he is carrying out his activity, within a period of no more than 15 (fifteen) days [121]. Where a network operator or a supplier of telecommunications services does not comply with the notice provided for above, the TRB may be given a one month suspension; one year reduction of the duration of his authorisation; or withdrawal of the authorization [122]. Without prejudice to the penalties provided for in Section 41 (2), where the breach is not a criminal offence, the Board may inflict on the offender a penalty of from 5 (five) million to 250 (two hundred and fifty) million francs[ 123 ]. However, where the breach constitutes a criminal offence, the file shall be forwarded to the State Counsel's chambers for judicial

118 See Article 5 of Decree No.2012/203 of April 20, 2012, on the Organisation and Functioning of the Telecommunications Regulatory Board.

${ }^{119}$ International Telecommunication Union (ITU), Op. Cit., p.176.

120 'Domestic Enforcement of Telecommunications Laws: Guidelines for the International Community', Report on ITU-D Question 18/1, 2005, p.4. Cited in International Telecommunication Union (ITU), ICT Regulation Toolkit, Module 6. Legal and Institutional Framework, p.176.

${ }^{121}$ See Article 41 (1) of Law n ${ }^{\circ} 98$ / 014 of 14 July 1998 to govern Telecommunications in Cameroon.

${ }^{122}$ See Article 41 (2).

${ }^{123}$ See Article 41 (3). 
proceedings [ 124 ]. Penalties falling under the jurisdiction of the Board are pronounced after notification of the charges to the operator who has 3 (three) days, with effect from the notification, to consult the file and make its observations in writing [125].

\section{Sanctions and Appeal Procedures in Mobile Telecommunication Sector in Cameroon}

The ability to sanction operators is closely related to enforcement and consists of the ability of the regulator to establish a fault standard for violations as well as the level of fine applied due to the violation. Most regulators' competencies include the ability to impose sanctions in order to enforce compliance with applicable laws, regulations, and licence conditions [126]. It is also important to ensure that the severity of the sanction matches the severity of the violation. It is recommended that when determining the appropriate sanction to impose, regulators should consider aggravating and mitigating factors such as the severity of the violation, the resulting harm to users and service provision, the benefits that the offender derived from the violation, prior violations, repetition of violations, early admission of the violation, cooperation or refusal to cooperate with the investigation, and the economic and financial situation of the offender [127].

Although the sanctions defined under the 1998 telecommunications law are of judicial competences [128]. The TRB has the power to imposed sanctions in the framework of the exercise of its duties [129]. In addition to the sanctions provided for under article 41(2) of the 1998 telecommunications law - the TRB can impose monetary sanctions [130]. The 2010 law on electronic communications in Cameroon has a specific schedule of fines, without the ability to issue penal (criminal) sanctions [131]. The TRB has the power to issue monetary sanctions in cases of refusal to grant interconnection, operation of network without permit, exploitation of fraudulent networks, infringement of decision to suspend operation networks, failure to provide information related to identification of subscribers and terminal, and all other relevant information concerning interconnection obligations, radiofrequencies, audit of accounts etc. All such

\footnotetext{
${ }^{124}$ See Article 41 (4).

${ }^{125}$ See Article 41 (5).

${ }^{126}$ See Article 4 of Decree No.2012/203 of April 20, 2012, on the Organisation and Functioning of the Telecommunications Regulatory Board.

${ }^{127}$ International Telecommunication Union (ITU), Op. Cit., p.179.

${ }^{128}$ See Articles 53 et seq. of Law n ${ }^{\circ} 98$ / 014 of 14 July 1998 to govern Telecommunications in Cameroon.

${ }^{129}$ See Article 41 (2) \& (5) of Law n ${ }^{\circ} 98$ / 014 of 14 July 1998 to govern Telecommunications in Cameroon.

${ }^{130}$ See Article 41 (3).

${ }^{131}$ See article 41(4).
}

penalties are pronounced by the TRB, and the monetary sanctions collected by it[132].

In addition to the abovementioned sanctions, the TRB can sanction actions that causes the disruption of electronic communications by way of reparation; award warnings and dismantlement of equipment; and in certain cases that threaten the security of the State, the President of the Republic may prescribe to operators and service providers, any measures from restriction of access to temporary suspension of certain electronic communications services, throughout or in some parts of the national territory[133]. It is therefore, evident that the telecommunications legislation neither allows for criminal sanctions nor the authority to impose prison sentences, but has the jurisdiction to refer violations for criminal prosecution to the courts or the proper authorities[134].

The ordinary law jurisdiction does not act like an appellate jurisdiction, or is the TRB dotted with an appeal body. The 1998 telecommunication law simply states that 'each party shall reserve the right to refer the matter to the competent legal authority in accordance with the procedure and time-limit...' [135] The appeal process is through the use of an arbitrator, where the TRB's ruling is contested by one of the parties. Curiously, it is the TRB which designates one or mare arbitrators, inform the parties in conflict and give them a time-limit within which to plead their cases [136]. The most controversial provision is article 37 (4) of the 1998 Telecommunications Law. It states that 'The appeal shall not stay execution. However, a stay of execution may be ordered by the court of appeal after a representative of the Board has been heard'. This provision is controversial because it suggests that the competent legal authority is an appellate jurisdiction, thereby indicating a double degree jurisdiction.

\section{CONCLUSION AND THE WAYFORWARD}

It is crystal clear from the forgoing that telecommunications is the main driver of mobile telephony access in Cameroon; the regulation of the mobile telephony sector, is an important policy area, which needs to be transparent, coherent, and comprehensive. The establishment of appropriate legal, policy and institutional frameworks, liberalising network industries, advocating and enforcing competition policy and law and opening external and internal markets to trade and investment, are pivot of the success in the telecommunication sector. From the

\footnotetext{
${ }^{132}$ See Article 69 (11) \& (12)

${ }^{133}$ See Articles 70, 71, \& 72 of Law No.2010/013 of 21 December 2010, regulating Electronic Communication in Cameroon.

${ }^{134}$ See Article 41(4) of Law n ${ }^{\circ} 98$ / 014 of 14 July 1998 to govern Telecommunications in Cameroon.

135 See Article 37(3).

${ }^{136}$ See Article 37(2).
} 
infrastructural debacles to the service offers and penetration, it is obvious that much is still desired, far above the means and regulatory environment. If not, what is certain is that the cost of telephone calls (especially mobile) remain relatively high; Internet fees, relatively high compared to income levels in Cameroon for provision of service at acceptable speed, which are consumer obstacles to mobile telephony demand in Cameroon. From the forgoing, we therefore, recommend the following:

Firstly, there is an urgent need to establish clear and specific regulatory quality principles, in particular the explicit adoption of the benefit/cost principle, and clarity as to the results to be achieved. Establish institutional and strategic support to sustain the policy, with responsibility being of paramount concern in the face of success.

Secondly, the Government of Cameroon should launch a public consultation to companies and public and private organizations partners, to contribute to the definition of actions needed to implement and guide decision-making to better position Cameroon among states seeking to develop their digital economy. This recommendation is the development of a roadmap related to digital economy.

Thirdly, the government should revisit laws on the telecommunication sector in Cameroon. Bearing in mind that archaic laws, old regulatory regimes and overlapping and conflicting authorities can all greatly complicate or halt the implementation of projects, the development of a new regulatory framework. Specifically the following actions are recommended:
Fourthly, collaborative and concerned action is needed, where telecom stakeholders, including government, citizens, the private sector, civil society, academia, media and international organisations based in Cameroon should collaborate in the search for crimefree cyberspace.

Aboveall, we recommend that local expertise should be employed to produce effective security personnel that master the ICT related risks; collaborate with legal, law enforcement and technical professionals; and scan best practices globally to create local processes. It is necessary to create local knowledge based on well recognised standards, to answer specific local needs by integrating local cultural values in national standards, which may be derived from international standards.

Lastly, Training of law enforcement officers is further necessary to introduce training initiatives to help fight against telecoms regulation offences, in order to deliver secure and effective regulation processes. Training should be conducted on a regular basis and private-public partnerships in training should form the basis for capacity building.

From the problems raised in this article, one may conclude that the regulatory framework that regulates mobile telecommunication sector in Cameroon is a curse but this curse can be turn into a blessing by putting these recommendations and those proffered in the forgoing of this article into pratice and effectively adhered to. 